\title{
Influence of two different feeding strategies in the dry period on dry matter intake and plasma protein peroxidative and antioxidative profile during dry period and early lactation
}

Yasmin Gundelach ${ }^{1 *}$, Beate Streuff ${ }^{2}$, Monika Franczyk ${ }^{3}$, Marta Kankofer ${ }^{3}$ and Martina Hoedemaker ${ }^{1}$

\begin{abstract}
Background: Dairy cows undergo dramatic changes in endocrine and metabolic status around parturition and in early lactation. Meeting the nutritional requirements of transition dairy cows is important for animal health, production and animal wellbeing. Dry cow feeding and managing play an essential role in this. The changes in metabolism of periparturient cows also lead to a rise in the production of oxidising agents, leading to oxidative stress. The relationship between dry cow diet composition and oxidative stress has received little research attention so far. In the present study, the influence of two different dry cow feedings (single diet with medium energy content over the whole dry period versus traditional two-phase diet with a low-energy "far-off" ration and a high energy "close-up" ration) on dry matter intake, energy intake and plasma protein peroxidative and antioxidative profile was investigated.

Results: The examined parameters revealed a dynamic profile within the experimental period. Dry matter intake (DMI) did not differ between groups. However, there was a time and a group x time interaction effect: Group 1 ("one-phase") had a very constant DMI with a slow and even decrease until calving. In Group 2 ("two-phase"), an initial increase in DMl two weeks antepartum (a.p.) was followed by a sharp drop at week 1 a.p.. The highest total antioxidant capacity and sulfhydryl residue concentration was noted at partus. In contrast, concentration of formylokinurenine and bityrosine bridges as representatives of protein peroxidation were lowest at parturition. The time course of formylokinurenine and bityrosine bridges showed parallels to the DMI. The contents of sulfhydryl groups, formylokinurenine and total antixoxidant capacity did not differ between groups. In contrast, concentration of bityrosine bridges was always higher in Group 2 compared with Group 1 and these differences were statistically significant at week 3 a.p., week 2 a.p., week 1 a.p. and at parturition.
\end{abstract}

Conclusion: The results of our study suggest time-related changes of pro- and antioxidative plasma parameters. Different dry cow feeding affected antepartal DMI. Furthermore, DMI and diet compositions seemed to have an influence on plasma protein peroxidative profile and activity of antioxidative defence.

Keywords: Dairy cow, Dry period, Oxidative stress, Diet, Dry matter intake

\footnotetext{
* Correspondence: yasmin.gundelach@tiho-hannover.de

${ }^{1}$ Clinic for Cattle, University of Veterinary Medicine Hannover, Foundation, Hannover, Germany

Full list of author information is available at the end of the article
}

C C The Author(s). 2020 Open Access This article is licensed under a Creative Commons Attribution 4.0 International License, which permits use, sharing, adaptation, distribution and reproduction in any medium or format, as long as you give appropriate credit to the original author(s) and the source, provide a link to the Creative Commons licence, and indicate if changes were made. The images or other third party material in this article are included in the article's Creative Commons licence, unless indicated otherwise in a credit line to the material. If material is not included in the article's Creative Commons licence and your intended use is not permitted by statutory regulation or exceeds the permitted use, you will need to obtain permission directly from the copyright holder. To view a copy of this licence, visit http://creativecommons.org/licenses/by/4.0/ The Creative Commons Public Domain Dedication waiver (http://creativecommons.org/publicdomain/zero/1.0/) applies to the data made available in this article, unless otherwise stated in a credit line to the data. 


\section{Background}

The dry period, in particular the transition period, is characterised by dramatic changes in endocrine and metabolic status. The increase in energy demands required after calving for milk production in high-yielding dairy cows and the concomitant insufficient dry matter intake (DMI) lead to a negative energy balance in early lactation $[1,2]$. Dry cow feeding and managing should prepare the cow for the next lactation as well as possible. Nutritional strategies have varied during the last decades. Traditionally, the dry period is divided into two feeding periods. In the "far-off" period, cows are fed a high-fibre, low-energy diet for the first weeks of the dry period. This is followed by a "close-up" period, typically 3 weeks long, during which cows are fed a diet with higher energy densitiy. As dry matter intake drops markedly before calving, increase in energy content in the close-up period may improve production and health in early lactation [3, 4]. In addition, it was shown that DMI was increased in the prepartum period when higher energy diets were fed $[3,5,6]$. In contrast, several authors have reported that overfeeding especially during the early dry period might lead to appetite depression and an increased incidence of health disorders [7-10]. Therefore, feeding cows a single controlled energy diet prepartum had beneficial effects on metabolic health $[8,10,11]$. Dry matter intake remained more constant in the transition period, when high-straw, low energy diets were fed [7]. In addition, single-group systems would have the advantage of eliminating a group change, which may then decrease social stress $[12,13]$. Due to the high metabolic demands and dysfunctional inflammatory responses, cows routinely experience substantial oxidative stress in early lactation $[14,15]$. Several studies suggested that oxidative stress increased the susceptibility of dairy cows to diseases [15-17]. Sordillo and Aitken [15] hypothesised that oxidative stress during the transition period may be a major underlying cause of inflammatory and immune dysfunction in dairy cattle. Measuring the concentration of peroxidation end products is a widely used method for the assessment of oxidative stress. Proteins are extremely sensitive to the action of free radicals. The oxidative modification of proteins is faster and linear (with regards to time and concentration) than the lipid peroxidation process. Therefore, concentration of protein peroxidation products is a sensitive indicator of the action of reactive oxygen species (ROS) on the cellular components [18]. Indicators of protein peroxidation are sulfhydryl residue groups, $\mathrm{N}^{\prime}$-formylkinurenine and bityrosine.

A number of antioxidant-related micronutrients were shown to affect various aspects of the immune system. For example, several studies revealed significant reductions in the incidence of retained foetal membranes, cystic ovarian disease and mastitis following supplementation with vitamin E or Se [19-23]. A study by Mantovani et al. [24] investigated the modifications of blood oxidative stress indicators in response to the omission of the dry period. Their results supported the hypothesis that diet composition rather than milk synthesis and secretion effected levels of oxidative stress in the continuously milked group. The aim of the current study was to evaluate the influence of two different dry cow feedings (single diet with medium energy content over the whole dry period versus traditionally two-phase diet with low-energy "far-off" ration and high energy "close-up" ration) on dry matter intake, plasma protein peroxidative profile and activity of antioxidative defence.

\section{Results}

The least squares means of antioxidant and oxidant blood concentrations as well as dry matter intake and energy intake are depicted in Fig. 1. It illustrates the time pattern of DMI, energy intake, bityrosine bridges (BIT), formylokinurenine (FK), total antioxidant capacity (TAC) and sulfhydryl residue (SH) ( $P$-values of temporal patterns are mentioned in Additional file 1).

\section{Dry matter- and energy intake}

Dry matter intake did not differ between groups, but a time and a group $\mathrm{x}$ time interaction effect were evident (Fig. 1 a). In Group 1, DMI decreased slowly during the dry period and reached the lowest value at partus. Comparing week 5 a.p. with the following antepartum values, this decrease was significant at the time of partus $(P<0.05)$. Postpartum (p.p.) DMI increased again. The time course of DMI in Group 2 revealed a slight decrease up until week 3 a.p. followed by a significant increase 1 week a.p. coinciding with feeding the more energetic ration. As in Group 1, DMI decreased in the last week before parturition and started to increase from week 2 p.p. onwards $(P<0.05)$.

Energy intake showed the same time and interaction effect in both groups as DMI (Fig. 1 b). However, in Group 2 , antepartum energy intake increased significantly already 2 weeks a.p.. Postpartum energy intake increased in group 1 at week 1 p.p. compared with parturition, whereas in Group 2, it did not increase until week 2 p.p. $(P<0.05)$.

\section{Bityrosine bridges}

The concentration of bityrosine bridges showed a clear time and group effect, but no group $\mathrm{x}$ time interaction (Fig. 1 c). In Group 1, BIT decreased slowly until parturition (week 5 a.p. vs. parturition: $P<0.05$ ). In Group 2, BIT increased from week 5 a.p. to week 3 a.p., followed by a decrease until parturition (week 5 vs. partus: $P<$ 0.05). With $0.0020 \mathrm{mg} / \mathrm{g}$ plasmaprotein and $0.0025 \mathrm{mg} / \mathrm{g}$ plasmaprotein, in both groups, the lowest concentrations of BIT were detected at parturition. After parturition, BIT values increased significantly in both groups (partus vs. the following weeks: $P<0.05$ ). Concentrations of BIT 


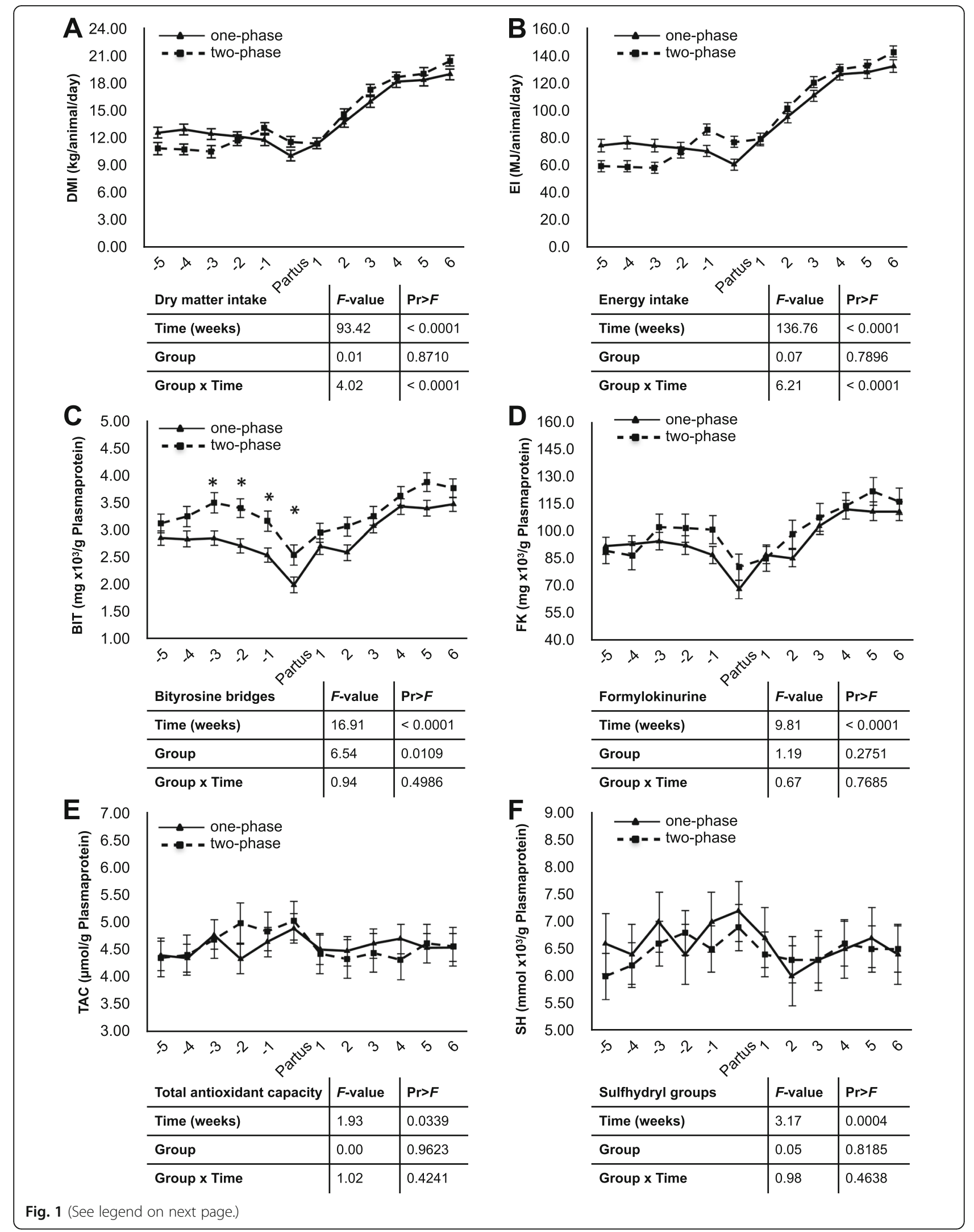


(See figure on previous page.)

Fig. 1 (a) dry matter intake (DMI) (kg/animal/day); (b) energy intake (EI) (MJ/animal/day); Mean concentrations \pm SE of [c] bityrosine bridges (BIT) (mgx $10^{3} / \mathrm{g}$ Plasmaprotein); (d) formylkinurine (FK) (mgx $10^{3} / \mathrm{g}$ Plasmaprotein); (e) total antioxidant capacity (TAC) ( $\mu$ mol/g Plasmaprotein); (f) sulfhydryl residues (SH) (mmolx $10^{3} / \mathrm{g}$ Plasmaprotein) in blood plasma of "one-phase" and "two-phase" fed cows from five weeks a.p. up to six weeks p.p.. Results of the SAS mixed model indicating significant $(p<0.05)$ differences regarding the fixed effects of group, time and group $\times$ time are shown in the respective tables under the graphs. * indicates significant differences between groups

were always higher in Group 2 compared with Group 1. The differences were statistically significant at week 3 a.p., week 2 a.p., week 1 a.p. and parturition $(P<0.05)$.

\section{Formylokinurenine}

For the concentrations of formylokinurenine, the time course was quite similar to the temporal pattern of BIT. No group $x$ time interaction or group effect was observed. (Fig. 1 d). Similar to BIT, the lowest values for FK were measured at parturition (Group 1: $0.07 \mathrm{mg} / \mathrm{g}$ plasmaprotein; Group 2:0.08 $\mathrm{mg} / \mathrm{g}$ plasmaprotein). Whereas in Group 1, FK concentrations at partus were significantly lower than at week 5 a.p. $(P<0.05)$, FK concentrations in Group 2 significantly increased from weeks 5 to 3 a.p. and 2 a.p. $(P<0.05)$, followed by a decrease until partus. As opposed to Group 1 and to BIT, the difference between week 5 and the day of partus was not significant $(P>$ 0.05). Postpartum, the concentration of FK increased starting at week 1 p.p. in Group 1 and at week 3 p.p. in Group 2 , respectively $(P<0.05)$.

\section{Total antioxidant capacity}

For the TAC concentration means, no statistically significant effects existed between groups, nor was there a significant group $\mathrm{x}$ time interaction (Fig. $1 \mathrm{e}$ ). With respect to the temporal pattern, in Group 1, TAC concentrations did not differ antepartum and postpartum $(P>0.05)$. Cows in Group 2 exhibited a significant increase in TAC concentrations from week 5 ap to weeks $-2,-1$ and partus $(P<0.05)$.

Postpartum, the TAC concentrations at weeks $1,2,3$ and 4 were lower than the values at partus $(P<0.05)$. Thereafter, the TAC concentrations increased again. However, they did not reach the concentrations at partus. For both groups, the highest TAC values were found at parturition.

\section{Sulfhydryl residue}

Similar to the TAC values, there were no statistically significant differences between groups or an interaction effect, but a time effect was observed (Fig. $1 \mathrm{f}$ ). The highest mean concentrations in thiol groups were measured at parturition $(P<0.05)$ in both groups. The lowest $\mathrm{SH}$ concentrations were measured at weeks 2 p.p. and 3 p.p. in both groups.

Within Group 1, the SH concentration remained constant antepartum, but increased towards parturition $(P<$
0.05). Postpartum, $\mathrm{SH}$ values decreased and remained from week 2 p.p. at a significantly lower level compared with parturition $(P<0.05)$. Cows in Group 2 exhibited an increase in $\mathrm{SH}$ concentrations from week 5 to week 3 and the following antepartal weeks and partus $(P<0.05)$. SH concentrations were lower at week 2 p.p. and 3 p.p. compared with partus $(P<0.05)$. Even though there was a slight increase thereafter, the concentration levels remained below those at parturition $(P>0.05)$.

\section{Energy-corrected milk yield (ECM)}

ECM did not differ between groups, but a time and a group $\mathrm{x}$ time interaction effect were evident (Fig. 2). In both groups, ECM increased significantly in the first 6 weeks p.p.. Cows from Group 1 have a slightly higher milk yield in the first 2 weeks, but due to the steep rise in ECM in group two, this relationship is reversed from week 3 p.p. onwards.

\section{Discussion}

To our knowledge, this is the first reported investigation of two different diets in the dry period on plasma antioxidative (TAC, content of SH groups) and oxidative (content of bityrosine bridges and formylokinurenine) profiles.

In our study, animals in Group 1 had a very constant DMI with a slow and even decrease until calving. Several studies confirmed that a higher concentration of neutral detergent fibre (NDF) in the last weeks before calving successfully prevented a rapid decrease in prepartum DMI [7, 9]. In Group 2, an initial increase in DMI caused by feeding the high-energy close-up ratio 2 weeks a.p. was followed by a sharp drop in the last week before parturition. This finding corresponds to the observations made in other studies that increasing the nutrient density of the diet could increase DMI [6,25]. In contrast, Vandehaar et al. [26] compared different energy and protein contents for the close-up ration and found no difference in the feed intake ante partum. Rabelo et al. [6] supposed that the greater the energy intake prepartum, the greater the magnitude of drop in DMI at parturition. In our study, the different dry cow diets did not have any significant effect on DMI and ECM postpartum. Previous studies came to very different results. For example, Doepel et al. [27] found positive effects on postpartal DMI but not improved lactation performance when feeding a closeup diet with higher energy density. This contrasts with the findings in several studies supporting a negative influence 


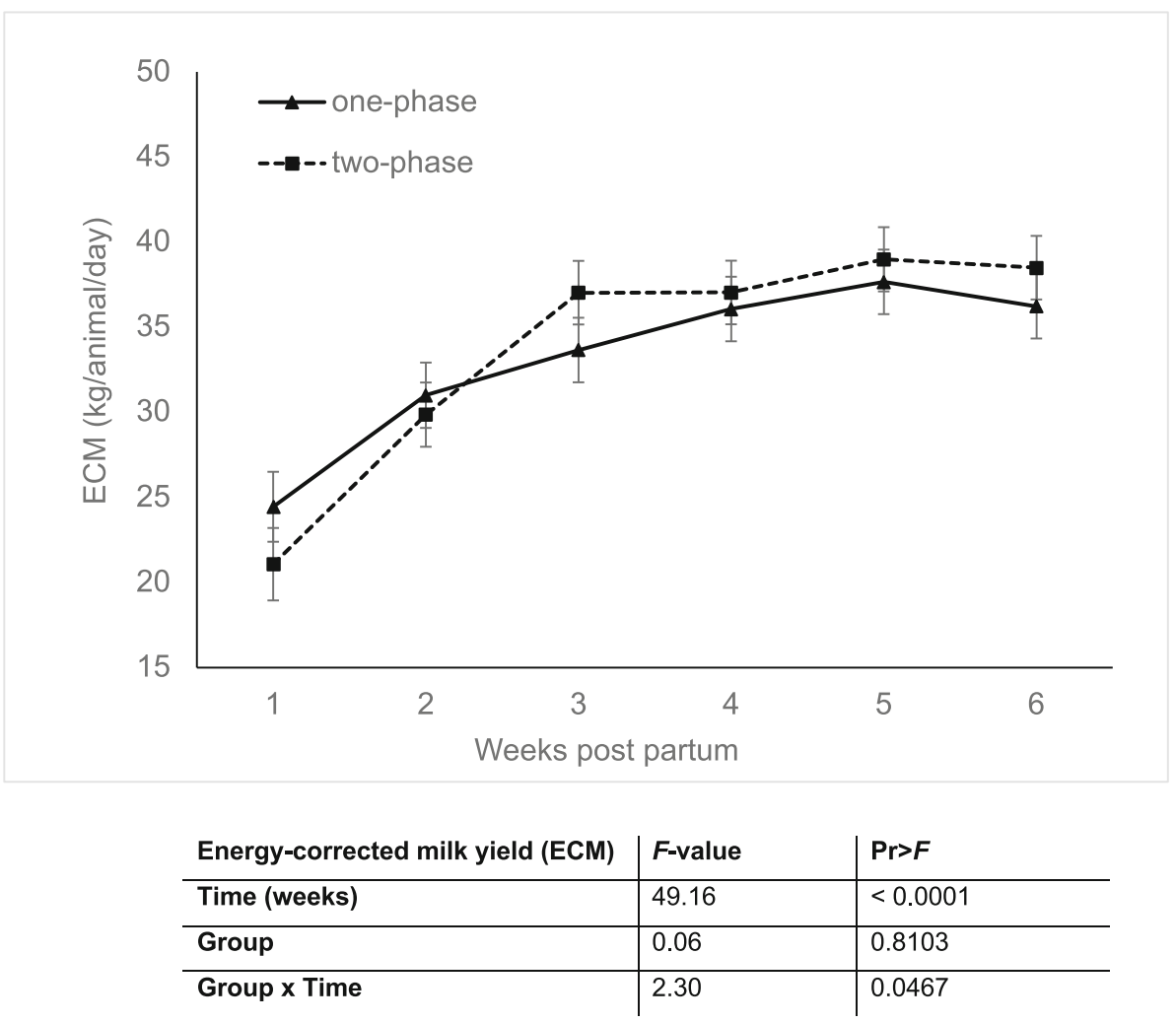

Fig. 2 Energy-corrected milk yield (ECM, kg/animal/day) of "one-phase" and "two-phase" fed cows in the first six weeks of lactation. Results of the SAS mixed model indicating significant $(P<0.05)$ differences regarding the fixed effects of group, time and group $\times$ time are shown in the respective table under the graph

of antepartal energy overconsumption on postpartal DMI $[8,9]$. In the study by Huang et al. $[28]$ cows fed a low energy density diet during the close-up period had a significantly lower average DMI (3 weeks a.p. to 1 week a.p.) compared to cows fed a close-up diet with high density. In the last week before calving, however, the DMI for both treatments was not different. After parturition, the "low density" group had a higher average DMI (week 1 to week 5 p.p.) and milk yield (week 1 to week 10 p.p.) compared with the "high-density" group.

Protein peroxidation in plasma is an essential parameter of oxidative stress, and it can be used as an adequate marker to evaluate the level of oxidative stress in the organism. Peroxidative damage to proteins leads to the loss of their biological activity, molecule aggregation or fragmentation and finally may result in the modification of amino acid residues. Tryptophan is oxidised to formylokinurenine. As the result of the recombination of tyrosine radicals, bityrosine bridges are created [29].

Only a few existing publications focus on changes in bityrosine and formylokinurenine concentrations in plasma in the peripartal period of cattle.

In our study, the lowest concentrations of BIT and formylokinurenine were found at partus. In the study by
Hanschke et al. [30], FK and BIT decreased towards parturition and increased during the postpartum period. Kankofer et al. [31] found the lowest mean concentration of BIT 1 week p.p., with a slight increase at 2 weeks and 1 week before partus. In our study, both groups had a nearly identical time course postpartum. However, antepartum, we found significant differences between groups and the time course of these parameters also showed parallels to the DMI. The slow and constant decrease antepartum of the DMI in Group 1 seemed to be associated with an almost identical course of the parameters FK and BIT. However, this relationship could not be fully confirmed for Group 2. A possible explanation for the significantly higher BIT values in Group 2 could be the change from the far-off diet to the close-up diet. More pronounced changes in DMI and the correspondingly higher fluctuations in energy and protein intake could have led to higher concentrations of BIT and FK. The higher availability of peroxidation substrates may result in a higher rate of peroxidation products. Postpartum, as previously mentioned, DMI, BIT and FK concentrations were nearly identical in both groups. The observations by Mantovani et al. [24] indicated that diet composition rather than milk synthesis may influence 
the concentration of oxidative stress parameters. The study by Mantovani et al. [24] investigated the modifications of blood oxidative stress indicators in response to the omission of the dry period. They found greater blood glutathione peroxidase [GPx] activities in the experimental group fed the lactation diet aimed to support milk secretion, while the normally dried off group received a two-phase dry cow diet (lower energy density and higher $\mathrm{NDF} \%$ ) formulated in order to supply the nutritional requirements by NRC [42]. GPx activities also were not different between groups after calving when lactation started, and the two groups received a similar diet. Data from Gabai et al. [32] support the hypothesis that the diet starch content may contribute to alter the control of oxidative stress. They suppose that the increase of aminoacid utilization for gluconeogenesis due to lower insulin concentration could explain the lower total plasma glutathione concentration in cows feeding a low starch diet. For lactating sheep data by Sgorlon et al. [33] indicate that rapid modification of diet composition affects metabolic and oxidative homeostasis.

In our study, the lowest values of BIT and FK in both groups were found at parturition, whereas at the same time, TAC values were the highest.

In order to examine the intensity of pro- and antioxidative status, it is useful to determine the total capacity of antioxidative agents. TAC is an integrated parameter describing the dynamic balance between oxidising agents and antioxidants within plasma [34]. In order to reveal fundamental information on the antioxidant status of animals, it is useful to define the ferric reducing ability of plasma [35].

In our study, cows exhibited a slight upward trend 5 weeks a.p. to parturition, when the concentration reached the highest value. In contrast to Group 1, for Group 2, this increase was significant and coincided with the decreased BIT concentrations, which possibly represented a compensatory reaction. Kankofer et al. [31] reported slightly different time patterns. They observed a significant increase in the TAC concentration from 4 weeks a.p. until 5 days a.p., with a sharp drop at calving and re-growth until 3 weeks p.p., before another decrease occurred.

The concentration of thiol groups can also be used to determine the level of protein peroxidation [29]. By the oxidation of SH groups, which are elements of plasma proteins including antioxidant compounds, disulfide bridges are formed, reflecting the loss of antioxidant compensatory mechanisms [36]. Previously, it has been suggested that any decrease in SH groups may be the result of proteins damage, while the increase is an expression of increased antioxidative defence [29]. Here, examined animals had a slight increase in the concentration of SH groups at parturition followed by a decrease during the postpartum period. Hanschke et al. [30] also reported a significant increase between 3 weeks antepartum and partus and a decrease again between partus and 3 weeks postpartum. Depending on the behaviour of this parameter, it can be defined as representing pro- or antioxidative status. Therefore, in our case, the slight increase until parturition represented an increased antioxidative defence which was also reflected by higher TAC values. On the other hand, the postpartal decrease in $\mathrm{SH}$ might be an expression of increased oxidative stress also reflected by higher BIT and FK values.

From the development of the parameters over time, it can be seen that the cows in both groups were able to manage the oxidative stress level around parturition. The slightly higher protein peroxidase products in Group 2 seemed to be compensated by an increasing total antioxidative capacity antepartum. Postpartum, when the two groups of cows were kept under the same condition and feeding regime, no group differences in protein peroxidation were observed anymore.

\section{Conclusion}

The results of our study suggest that different dry cow diets influenced antepartal DMI and that the composition of the diet also seemed to have an impact on plasma protein peroxidative profile and activity of antioxidative defence. Due to the limited number of individuals, these results should be viewed with caution. Further studies are necessary to establish physiological ranges of antioxidative/ oxidative profiles in cows and their interrelation to DMI and different ration compositions.

\section{Methods \\ Animals}

All animal procedures were carried out in accordance with ethical guidelines for the use of animal samples, as approved by LANUV NRW (State Office for Nature, Environment and Consumer Protection; No. 8402.05.20.12-179).

Primi- and pluriparous cows of the German Holstein breed from the Agricultural Research and Teaching Centre Haus Riswick of the Chamber of Agriculture in Northrhine-Westfalia, Germany, were used in the present study from the beginning of the dry period or, in the case of heifers, 6 weeks before the calculated calving date until 50 days postpartum. At the end of the study, the animals were returned to the normal dairy herd. The trial lasted from April 2012 until December 2012. The two experimental groups consisted of 50 animals each. The animals in each group were matched according to the number of lactation, presumed dry period length, past estimated calving interval, past 305-day milk yield, body weight and first calving date (heifers). The animals in each pair were then randomly assigned to the experimental groups. In the further evaluation for this study, 20 animals per group were randomly selected. 


\section{Housing}

Dry cows and heifers were kept in a free stall barn with raised cubicles with mattresses covered with milled straw. The two feeding groups were housed in separate compartments until calving. Approximately two days before the expected calving date, the animals were moved to straw yards. Immediately after calving, the cows were moved to different straw yards, where the animals in both groups were mixed and were fed the same early lactation diet. After approximately five days, the cows were housed in a free stall barn, receiving the early lactation diet until 50 days postpartum.

\section{Feeding}

The nutrient and energy content for the different rations are depicted in Table 1.

Group 1 was fed a one-phase diet consisting of grass silage $(29.4 \%$ of dry matter (DM)), corn silage (34.9\% of $\mathrm{DM})$, straw $(21.2 \%$ of $\mathrm{DM})$, post-extraction rapeseed meal (RES) (13.8\% of DM) and minerals ( $0.8 \%$ of DM).

Group 2 was fed a two-phase diet. For phase 1 (drying off to two weeks ante partum), cows received a diet according to the guidelines of the GfE [37] consisting of grass silage $(63.3 \%$ of $\mathrm{DM})$, corn silage $(12.0 \%$ of $\mathrm{DM})$, straw (18.7\% of DM) and minerals (1.1\% of DM). Two weeks before the calculated calving date, cows received the transition diet consisting of grass silage $(27.8 \%$ of $\mathrm{DM})$, corn silage $(34.5 \%$ of $\mathrm{DM})$, straw $(6.3 \%$ of $\mathrm{DM})$, RES $(18.8 \%$ of $\mathrm{DM})$, concentrate $(11.9 \%$ of $\mathrm{DM})$ and minerals $(0.8 \%$ of DM). The diet was offered ad libitum and fed as a Total Mixed Ration (TMR).

After calving, all cows received the early lactation TMR consisting of grass silage (18.7\% of DM), corn silage ( $42.6 \%$ of DM), alfalfa hay (3.2\% of DM), RES (16.7\% of DM), concentrate $(16.2 \%$ of $\mathrm{DM})$ and minerals $(2.7 \%$ of $\mathrm{DM})$.

All diets were mixed once daily and offered in individual feeding troughs equipped with scales. Cows were recognised either by responders (Westfalia Separator Group GmbH, Oelde, Germany/Calan) or chip cards (Waagen Döhrn GmbH \& Co. KG, Wesel, Germany).
Every day, the DM of the different diets was determined by drying feed samples for $24 \mathrm{~h}$ at $105^{\circ} \mathrm{C}$ in a drying cabinet. The corrected DM was calculated using the formula in accordance with Weißbach and Kuhla [43]: DM corr $=2.08+0.957^{*} \mathrm{DM}(\%)$. From the daily values of DM intake, a weekly average was calculated and the energy intake was calculated using the dry mater intake and the estimated values for metabolisable energy. Analysis of the nutrient content was performed according to the guidelines of the Association of German Agricultural Analytic and Research Institutes [38], and method numbers are given. Crude protein and neutral detergent fibre after treatment with amylase and cinefaction (aNDFom) were analysed using methods 4.1 .1 and 6.5.1., respectively. Starch was determined using method 7.2.1 and sugar using method 7.1.3. Energy content and utilisable crude protein at the duodenum $(\mathrm{uCP})$ were calculated according to GfE [37].

On an individual level, milk production was recorded for every milking. Fat, protein, and lactose contents in milk were measured weekly. Energy-corrected milk $(\mathrm{ECM}) / \mathrm{kg}$ per day and cow was calculated as follows: $E C M=0.327 \times$ milk yield $(\mathrm{kg} / \mathrm{d})+12.95 \times$ fat $\quad(\mathrm{kg} / \mathrm{d})+$ $7.2 \times$ protein $(\mathrm{kg} / \mathrm{d})$.

\section{Blood sampling}

From the beginning of drying off onwards, blood samples were taken at weekly intervals, at the day of calving and then at weekly intervals until 6 weeks post partum. Blood samples were collected from the Vena caudalis mediana in EDTA-tubes and centrifuged for $15 \mathrm{~min}$ at $9000 \mathrm{rpm}$. The plasma was aliquoted in Eppendorf vials (1.5 mL, Sarstedt AG \& Co. KG, Nürmbrecht, Germany) and stored at $-20^{\circ} \mathrm{C}$ until further analysis.

\section{Protein content}

The protein content of the plasma samples was measured by the biuret method using commercial assay kits (PZ Cormay S.A., Łomianki, Poland).

Table 1 Nutrient and energy content of the dry cow diets in group 1 and group 2 and the lactating diet

\begin{tabular}{|c|c|c|c|c|}
\hline \multirow[t]{2}{*}{ Nutrient and energy content } & \multirow[t]{2}{*}{$\begin{array}{l}\text { Group } 1 \\
\text { "one-phase" }\end{array}$} & \multicolumn{2}{|c|}{$\begin{array}{l}\text { Group } 2 \\
\text { "two-phase" }\end{array}$} & \multirow[t]{2}{*}{ Lactation } \\
\hline & & Phase $1^{7}$ & Phase $2^{\mathbf{8}}$ & \\
\hline $\mathrm{DM}(\mathrm{g} / \mathrm{kg})^{1}$ & 466 & 458 & 511 & 477 \\
\hline $\mathrm{uCP}(\mathrm{g} / \mathrm{kg} \mathrm{DM})^{2}$ & 133 & 118 & 152 & 155 \\
\hline $\mathrm{RNB}(\mathrm{g} / \mathrm{kg} \mathrm{DM})^{3}$ & -0.5 & -1.7 & 0.5 & 0.2 \\
\hline aNDFom (g/kg DM) ${ }^{4}$ & 491 & 534 & 414 & 371 \\
\hline Degradable XS + XZ (g/kg DM) ${ }^{5}$ & 155 & 99 & 190 & 202 \\
\hline NEL (MJ/kg DM) ${ }^{6}$ & 5.95 & 5.55 & 6.60 & 6.95 \\
\hline
\end{tabular}

${ }^{1} D M$ Dry matter; ${ }^{2} u C P$ Utilisable crude protein; ${ }^{3} R N B$ Ruminal nitrogen balance; ${ }^{4}$ aNDFom $=$ Neutral detergent fibre after treatment with amylase and cinefaction; ${ }^{5}$ degradable XS $+\mathrm{XZ}=$ degradable starch + sugar; ${ }^{6} \mathrm{NEL}$ Net energy for lactation, Phase $1^{7}=$ Date of drying off to two weeks ante partum, Phase $2^{8}=$ Two weeks ante partum until partus 


\section{Content of bityrosine bridges}

Bityrosine bridges were determined by a spectroflurimetric method in accordance with Rice-Evans et al. [39]. The unaltered plasma sample was excited by light at $325 \mathrm{~nm}$ and emission was measured at a wavelength of $410 \mathrm{~mm}$. The spectrofluorimeter (Jasco Corporation, Tokyo, Japan) was standardised to 100 deflections with chinine sulphate $\left(0.1 \mu \mathrm{g} / \mathrm{mL}\right.$ in $\left.0.1 \mathrm{~mol} / \mathrm{H}_{2} \mathrm{SO}_{4}\right)$ at excitation $(350 \mathrm{~nm})$ and emission wavelength $(445 \mathrm{~nm})$. The results were expressed as $\mathrm{mg} / \mathrm{g}$ plasmaprotein. The coefficients of variation were: intra-assay $5.9 \%(n=10)$ and inter-assay $6.0 \%(n=10)$, respectively.

\section{The content of formylokinurenine}

Formylokinurenine was determined by a spectroflurimetric method in accordance with Rice-Evans et al. [39]. The unaltered plasma sample was excited by light at 360 $\mathrm{nm}$ and emission was measured at $454 \mathrm{~nm}$ wavelength. The spectrofluorimeter (Jasco Corporation) was standardised as described above [39]. The results were expressed as $\mathrm{mg} / \mathrm{g}$ plasmaprotein. The coefficients of variation were: intra-assay 6.3\% $(n=10)$ and inter-assay 6.5\% $(n=10)$.

\section{The content of sulfhydryl groups}

The concentration of sulfhydryl residues in plasma was measured by spectrophotometry as described in detail by Rice-Evans et al. [39]. A volume of $300 \mu \mathrm{L} 10 \%$ (w/v) sodium dodecyl sulphate (SDS, Sigma, Poznań, Poland) in 10 $\mathrm{mmol} / \mathrm{L}$ sodium phosphate buffer $(\mathrm{pH}$ 8.0) was added to $300 \mu \mathrm{L}$ of sample and mixed precisely. A $2.4 \mathrm{~mL}$ of 10 $\mathrm{mmol} / \mathrm{L}$ sodium phosphate buffer ( $\mathrm{pH} 8.0$ ) was added. Then $300 \mu \mathrm{L}$ of solution consisting of $20 \mathrm{mg}$ of 5,5-dithiobis-2-nitro benzoate (DTNB, Sigma Aldrich sp. z o.o., Poznań, Poland) in $50 \mathrm{~mL}$ of buffer (DTNB) was added and the absorbance was measured at $412 \mathrm{~nm}$. The control sample contained $300 \mu \mathrm{L}$ of the same buffer instead of DTNB. All samples were incubated for $1 \mathrm{~h}$ at $37^{\circ} \mathrm{C}$. After incubation, the absorbance was measured again at $412 \mathrm{~nm}$. The difference in absorbance before and after incubation (after subtracting the respective absorbance of the control) referred to the content of the SH groups. The content was calculated using a standard curve prepared with different dilutions of glutathione (GSH, Sigma Aldrich sp. z o.o.) ranging from 0 to $1 \mathrm{mmol} / \mathrm{L}$ in $10 \mathrm{mmol} / \mathrm{L}$ sodium phosphate buffer ( $\mathrm{pH}$ 8.0) and expressed in $\mathrm{mmol} / \mathrm{g}$ plasmaprotein. The intra-assay coefficient of variation was $6.9 \%(n=10)$ and the inter-assay coefficient of variation was $7.1 \%(n=10)$.

\section{Total antioxidant capacity}

Total antioxidant capacity was measured in accordance with the method of Benzie and Strain [40], based on the ferric reducing ability of plasma with some modifications. The changes in absorbance were directly related to the "total" reducing capacity of the electron donating antioxidants present in the examined plasma samples. The working reagent contained $300 \mathrm{mmol} / \mathrm{L}$ acetate buffer $(\mathrm{pH}$ 3.6), $10 \mathrm{mmol} / \mathrm{L}$ 2,4,6-tri-pyridyl-striazine (TPTZ, Sigma Aldrich sp. $\mathrm{z}$ o.o.) solution in $40 \mathrm{mmol} / \mathrm{L}$ hydrogen chloride and $20 \mathrm{mmol} / \mathrm{L} \mathrm{FeCl}_{3} \times 6 \mathrm{H}_{2} \mathrm{O}$ solution in $\mathrm{dH}_{2} \mathrm{O}$ mixed at a ratio of 10:1:1. The working reagent was prepared immediately before use. The working reagent $(2250 \mu \mathrm{L})$ was mixed with $25 \mu \mathrm{L}$ of plasma and absorbance was measured at 593 $\mathrm{nm}$. The absorbance of the working reagent alone served as control. After a 10-min incubation-period at room temperature, the absorbance was measured again. The difference in absorbance at zero and at $10 \mathrm{~min}$ was compared with a standard curve prepared with ten different dilutions of Fe (II) between 0 and $1000 \mu \mathrm{mol} / \mathrm{L}$. The results were expressed as $\mu \mathrm{mol} / \mathrm{g}$ plasmaprotein. Intra-assay $8.8 \%(n=$ $10)$ and inter-assay $8.5 \%(n=10)$ coefficients of variation were established.

\section{Statistical analysis}

Statistical analysis was performed applying standard statistical procedures [41] and using the computer program SAS version 9.1 (SAS Institute Corp., Cary, NC USA). All results are presented as least square mean (LSM) \pm standard error (SE). For comparing mean concentrations of antioxidant and oxidant blood constituents, a linear mixed effect model for repeated measures was performed (PROC MIXED and method REML) with the following fixed effects: group (one-phase/two-phase) and time periods (week $-5,-4,-3,-2,-1$, Partus, $+1,+2$, $+3,+4+5,+6$; repeated) and group $\mathrm{x}$ time interaction. Cows were included as random effect. Analyses were followed by Tukey-Kramer test (LSMEANS/ADJUST = TUCKEY) for adjusted multiple comparisons between the groups and days, respectively. The $\mathrm{F}$ - and $p$ values for the effects time, group and group $\times$ time are presented in the Fig. 1 A-F. Significant differences between the groups (one-phase/two-phase) are indicated by asterix. For the study of temporal patterns, we initially compared all points in time with each other. Due to the correspondingly high number of comparisons and under consideration of relevant time periods, the presentation of the data was limited to the observation of the antepartum and postpartum periods. Accordingly, 5 weeks a.p. was compared with the following time points until partus. To consider the postpartum period, a comparison was made between day of parturition and all following time points. The level of significance was set at $P<0.05$.

\section{Supplementary information}

Supplementary information accompanies this paper at https://doi.org/10. 1186/s12917-020-02347-x.

Additional file 1 Least squares means \pm SE of dry matter intake $(\mathrm{kg} /$ animal/day), energy intake (MJ/animal/day) and arithmetic mean 
concentration of bityrosine bridges, formylkinurine, sulfhydryl residues, total antioxidant capacity in blood plasma of "one-phase" $(n=20)$ and "two-phase" $(n=20)$ fed cows from five weeks a.p. up to six weeks p.p.. $P$ value for the time comparison within the groups.

\section{Abbreviations}

aNDFom: Neutral detergent fibre after treatment with amylase and cinefaction; a.p.: Antepartum; BIT: Bityrosine bridges; XS: Starch; XZ: Sugar; DM: Dry matter; DMI: Dry matter intake; DTNB: 5,5-Dithiobis-2-nitro benzoate; ECM: Energy-corrected milk yield; FK: Formylokinurenine; GPx: Glutathione peroxidase; GSH: Glutathione; LSM: Least square mean; NDF: Neutral detergent fibre; NEL: Net energy for lactation; p.p.: Postpartum; RES: Postextraction rapeseed meal; RNB: Ruminal nitrogen balance; ROS: Reactive oxygen species; SDS: Sodium dodecyl sulphate; SE: Standard error; SH: sulfhydryl residues; TAC: Total antioxidant capacity; TMR: Total mixed ration; TPTZ: 2,4,6-Tri-pyridyl-striazine; uCP: Utilisable crude protein

\section{Acknowledgements}

Not applicable.

\section{Authors' contributions}

$\mathrm{MH}$ was the project manager. MK and $\mathrm{MH}$ planned the study. BS collected the data. MK and MF analysed blood samples and wrote the Material and Methods section. MH and YG performed the statistical analyses. YG wrote the main and final draft of this paper. All authors read the article and gave advice on how to improve it. The author (s) read and approved the final manuscript.

\section{Funding}

Not applicable.

\section{Availability of data and materials}

The datasets used and/or analysed during the current study are available from the corresponding author on reasonable request.

\section{Ethics approval and consent to participate}

The study was done according to the German Animal Welfare Law (released on 05/18/2006, last changes on 12/03/2015) and the animal care and use protocol was approved by the Animal Welfare Committee (State Office for Nature, Environment and Consumer Protection; AZ. 84-02.05.20.12-179).

\section{Consent for publication}

\section{Not applicable.}

\section{Competing interests}

The authors declare that they have no competing interests.

\section{Author details}

${ }^{1}$ Clinic for Cattle, University of Veterinary Medicine Hannover, Foundation, Hannover, Germany. ${ }^{2}$ Present Address: Educational and Research Centre for Agriculture, Haus Düsse, Ostinghausen, 59505 Bad Sassendorf, Germany. ${ }^{3}$ Department of Biochemistry, Faculty of Veterinary Medicine, University of Life Sciences, Lublin, Poland.

Received: 23 December 2019 Accepted: 29 April 2020

Published online: 13 May 2020

\section{References}

1. Goff JP, Horst RL. Physiological changes at parturition and their relationship to metabolic disorders. J Dairy Sci. 1997;80:1260-8.

2. Ingvartsen $\mathrm{KL}$, Andersen JB. Integration of metabolism and intake regulation: a review focusing on periparturient animals. J Dairy Sci. 2000;83: 1573-97.

3. Grummer RR. Impact of changes in organic nutrient metabolism on feeding the transition dairy cow. J Anim Sci. 1995;73:2820-33.

4. McNamara S, O'Mara FP, Rath M, et al. Effects of different transition diets on dry matter intake, milk production, and milk composition in dairy cows. J Dairy Sci. 2003;86:2397-408.
5. Holcomb CS, Van Horn HH, Head HH, et al. Effects of prepartum dry matter intake and forage percentage on postpartum performance of lactating dairy cows. J Dairy Sci. 2001;84:2051-8.

6. Rabelo E, Rezende RL, Bertics SJ, et al. Effects of transition diets varying in dietary energy density on lactation performance and ruminal parameters of dairy cows. J Dairy Sci. 2003;86:916-25.

7. Dann HM, Litherland NB, Underwood JP, et al. Diets during far-off and close-up dry periods affect periparturient metabolism and lactation in multiparous cows. J Dairy Sci. 2006;89:3563-77.

8. Douglas GN, Overton TR, Bateman HG 2nd, Dann HM, et al. Prepartal plane of nutrition, regardless of dietary energy source, affects periparturient metabolism and dry matter intake in Holstein cows. J Dairy Sci. 2006;89:2141-57.

9. Janovick NA, Drackley JK. Prepartum dietary management of energy intake affects postpartum intake and lactation performance by primiparous and multiparous Holstein cows. J Dairy Sci. 2010;93:3086-102.

10. Janovick NA, Boisclair YR, Drackley JK. Prepartum dietary energy intake affects metabolism and health during the periparturient period in primiparous and multiparous Holstein cows. J Dairy Sci. 2011;94:1385-400.

11. Vickers LA, Weary DM, Veira DM, et al. Feeding a higher forage diet prepartum decreases incidences of subclinical ketosis in transition dairy cows. J Anim Sci. 2013:91:886-94.

12. Cook NB, Nordlund KV. Behavioral needs of the transition cow and considerations for special needs facility design. Vet Clin North Am Food Anim Pract. 2004;20:495-520.

13. von Keyserlingk MA, Olenick D, Weary DM. Acute behavioral effects of regrouping dairy cows. J Dairy Sci. 2008;91:1011-6.

14. Sordillo LM, Contreras GA, Aitken SL. Metabolic factors affecting the inflammatory response of periparturient dairy cows. Anim Health Res Rev. 2009;10:53-63.

15. Sordillo LM, Aitken SL. Impact of oxidative stress on the health and immune function of dairy cattle. Vet Immunol Immunopathol. 2009;128:104-9.

16. Castillo C, Hernandez J, Bravo A, et al. Oxidative status during late pregnancy and early lactation in dairy cows. Vet J. 2005;169:286-92.

17. Castillo C, Hernandez J, Valverde I, et al. Plasma malonaldehyde (MDA) and total antioxidant status (TAS) during lactation in dairy cows. Res Vet Sci. 2006;80:133-9.

18. Colak E. New markers of oxidative damage to macromolecules. J Med Biochem. 2008:27:1-16.

19. Harrison $\mathrm{JH}$, Hancock DD, Conrad HR. Vitamin E and selenium for reproduction of the dairy cow. J Dairy Sci. 1984;67:123-32.

20. Smith $\mathrm{KL}$, Harrison $\mathrm{JH}$, Hancock DD, et al. Effect of vitamin $\mathrm{E}$ and selenium supplementation on incidence of clinical mastitis and duration of clinical symptoms. J Dairy Sci. 1984;67:1293-300.

21. Weiss WP, Hogan JS, Todhunter DA, et al. Effect of vitamin E supplementation in diets with a low concentration of selenium on mammary gland health of dairy cows. J Dairy Sci. 1997;80:1728-37.

22. Campbell MH, Miller JK. Effect of supplemental dietary vitamin $\mathrm{E}$ and zinc on reproductive performance of dairy cows and heifers fed excess iron. J Dairy Sci. 1998;81:2693-9.

23. Allison RD, Laven RA. Effect of vitamin E supplementation on the health and fertility of dairy cows: a review. Vet Rec. 2000;147:703-8.

24. Mantovani R, Sgorlon S, Marinelli L, et al. Oxidative stress indicators and metabolic adaptations in response to the omission of the dry period in dairy cows. J Dairy Res. 2010;77:273-9.

25. Minor DJ, Trower SL, Strang BD, et al. Effects of nonfiber carbohydrate and niacin on periparturient metabolic status and lactation of dairy cows. J Dairy Sci. 1998;81:189-200.

26. Vandehaar MJ, Yousif G, Sharma KB, et al. Effect of energy and protein density of prepartum diets on fat and protein metabolism of dairy cattle in the preparturient period. J Dairy Sci. 1999;82:1282-95.

27. Doepel L, Lapierre H, Kennelly JJ. Peripartum performance and metabolism of dairy cows in response to prepartum energy and protein intake. J Dairy Sci. 2002;85:2315-34.

28. Huang W, Tian $Y$, Wang $Y$, et al. Effect of reduced energy density of closeup diets on dry matter intake, lactation performance and energy balance in multiparous Holstein cows. J Anim Sci Biotechnol. 2014:5:30.

29. Kankofer M. Protein peroxidation processes in bovine retained and notretained placenta. J Vet Med A Physiol Pathol Clin Med. 2001:48:207-12.

30. Hanschke N, Kankofer M, Ruda L, et al. The effect of conjugated linoleic acid supplements on oxidative and antioxidative status of dairy cows. J Dairy Sci. 2016;99:8090-102 
31. Kankofer M, Albera E, Feldman M, et al. Comparison of antioxidative/ oxidative profiles in blood plasma of cows with and without retained fetal placental membranes. Theriogenology. 2010;74:1385-95.

32. Gabai G, Testoni S, Piccinini $R$, et al. Oxidative stress in primiparous cows in relation to dietary starch and the progress of lactation. Anim Sci. 2004;79: 99-108.

33. Sgorlon S, Stradaioli G, Gabai G, et al. Variation of starch and fat in the diet affects metabolic status and oxidative stress in ewes. Small Rumin Res. 2008; 74:123-9.

34. Guo Y, Xu X, Zou Y, et al. Changes in feed intake, nutrient digestion, plasma metabolites, and oxidative stress parameters in dairy cows with subacute ruminal acidosis and its regulation with pelleted beet pulp. J Anim Sci Biotechnol. 2013:4:31.

35. Konvičná J, Vargová M, Paulíková l, et al. Oxidative stress and antioxidant status in dairy cows during prepartal and postpartal periods. Acta Vet Brno. 2015;84:133-40

36. Maritim AC, Sanders RA, Watkins JB 3rd. Diabetes, oxidative stress, and antioxidants: a review. J Biochem Mol Toxicol. 2003;17:24-38.

37. [GFE] Society of Nutrition Physiology. Energy and nutrient requirements of livestock. Recommendations for energy and nutrient supply of dairy cows and breeding cattle. Frankfurt am Main: DLG-Verlag,2001.

38. [VDLUFA] Association of German Agricultural and Analytic Research Institutes-Handbook of Agricultural Research and Analytic Methods (VDLUFA Book of Methods). The chemical analysis of feedstuffs, vol. III. Darmstadt: VDLUFA-Verlag; 2007.

39. Rice-Evans CA, Symons MCR. Techniques in free radical research. Amsterdam: Elsevier; 1991.

40. Benzie IFF, Strain JJ. The ferric reducing ability of plasma (FRAP) as a measure of 'Antioxidative Power': the FRAP assay. Anal Biochem. 1996;239: 70-6.

41. Steel L, Torrie S. Principles and procedures of statistics: a biometrical approach. 2nd ed. New York: McGraw-Hill Book Company; 1980.

42. National Research Council [NRC] 2001. Nutrient requirements of dairy cattle: seventh revised edition. Washington DC, USA: National Academic Press; 2001.

43. Weißbach F, Kuhla S. Substance losses in determining the dry matter content of silage and green fodder: arising errors and possibilities of correction. Anim Feed [Übers. Tierernährung]. 1995;23:189-21.

\section{Publisher's Note}

Springer Nature remains neutral with regard to jurisdictional claims in published maps and institutional affiliations.

Ready to submit your research? Choose BMC and benefit from:

- fast, convenient online submission

- thorough peer review by experienced researchers in your field

- rapid publication on acceptance

- support for research data, including large and complex data types

- gold Open Access which fosters wider collaboration and increased citations

- maximum visibility for your research: over $100 \mathrm{M}$ website views per year

At $\mathrm{BMC}$, research is always in progress.

Learn more biomedcentral.com/submissions 